\title{
PENERAPAN METODE BERMAIN GAME DAN PENGARUHNYA TERHADAP KEMAMPUAN BERBICARA BAHASA INGGRIS MAHASISWA PADA MATA KULIAH SPEAKING 2
}

\author{
Siane Herawati \\ English Education department of University of Kanjuruhan Malang \\ Siane.herawati@yahoo.com \\ Muhammad Suharto \\ Maria Cholifah
}

\begin{abstract}
Abstrak
Penelitian ini dilakukan untuk: 1) Menguji pengaruh penerapan metode bermain game terhadap sikap mahasiswa pada mata kuliah speaking 2, 2) Menguji pengaruh penerapan bermain game terhadap penguasaan kosa kata bahasa Inggris 3) Menguji pengaruh penerapan bermain game terhadap penguasaan kalimat bahasa Inggris 4) Menguji pengaruh penerapan bermain game terhadap kemampuan komunikasi menggunakan bahasa Inggris.Penelitian ini dilaksanakan di Universitas Kanjuruhan Malang, pada mahasiswa Jurusan Bahasa Inggris tahun akademik 2015/2016. Metode penelitian yang digunakan adalah eksperimental. Dalam pengumpulan data, peneliti menggunakan wawancara, observasi, kuesioner, dukumen dan tes. Data kualitatif dianalisis dengan menggunakan Constant Comparative Method: membandingkan kejadian yang berlaku untuk setiap kategori, integrating categories and their properties, delimiting the theory, dan speaking the theory. Data kuantitatif dianalisis deskriptif dengan statistik Korelasi Product Moment untuk mencari nilai akhir. Peneliti mendapatkan banyak kemajuan setelah melakukan penelitian dengan menggunakan metode bermain game. Adapun dilihat pada kemampuan dan keberanian berbicara bahasa Inggris yang spontanitas serta penambahan kosa kata pada mahasiswa semester 2 tersebut.Hasil dari variabel X ( Strategi bermain game) dari 80 orang mahasiswa adalah 5831, sedangkan variabel Y (kemampuan berbicara bahasa Inggris) adalah 7189. Setelah dihitung dengan menggunakan korelasi Pearson Product Moment $r$ hitung adalah 0.8090. Dengan nilai 0.8090, jika diinterpretasikan sesuai dengan Interpretasi Koefisien Korelasi nilai r. Maka dapat disimpulkan bahwa nilai korelasi variabel X (bermain game) mempunyai pengaruh tingkat hubungan yang sangat tinggi terhadap variabel $\mathrm{Y}$ (kemampuan berbicara bahasa Inggris.
\end{abstract}

Kata-kata kunci: metode, bermain, game

\section{PENDAHULUAN}

Bahasa Inggris merupakan suatu bahasa yang sangat penting dalam dunia internasional terutama di era globalisasi sekarang ini. Bahasa Inggris digunakan untuk berkomunikasi dengan orang lain diberbagai negara. Dengan menguasai bahasa Inggris, orang akan bisa masuk dan mengakses dunia informasi dan teknologi. Dengan pengenalan bahasa Inggris di sekolah dasar, maka siswa akan mengenal dan mengetahui Bahasa Inggris lebih awal.
Sehingga, mereka akan mempunyai pengetahuan dasar yang lebih baik sebelum melanjutkan ke tingkat pendidikan yang lebih tinggi. Dengan menguasai bahasa Inggris maka seseorang bisa memiliki kesempatan yang lebih terbuka untuk mengembangkan diri guna memperoleh kesempatan yang lebih baik dalam menghadapi persaingan dalam dunia kerja di masa yang akan datang. Karena bahasa Inggris telah menjadi suatu alat yang sangat 
menentukan bagi kelanjutan pendidikan, pekerjaan serta status sosial masyarakat.

Saat ini peneliti sedang mengajar mata kuliah speaking dimana banyak sekali permasalahan yang muncul dalam mengajar speaking. Pelajaran speaking itu sendiri diajarkan dengan tujuan agar siswa memiliki kemampuan dalam menuangkan ide, gagasan, pendapat, dan ide untuk disampaikan kepada orang lain.Tetapi pelajaran speaking tidaklah mudah untuk di pelajari mengingat banyaknya faktor yang mempengaruhi selama ini. Berbagai faktor tersebut adalah: (1) karena mereka berasal dari berbagai sekolah menengah atas yang berbeda beda terutama dari daerah kabupaten, atau dengan kata lain lingkungan yang kurang mendukung sebelumnya, terbatasnya fasilitas, (3) kurangnya kosa kata atau faktor yang masih terjadi saat ini (4) mahasiswa merasa jenuh karena dosen yang mengajar monoton dan membiarkan siswa berbicara dengan ide sendiri sehingga menambah tingkat kesulitan bagi mereka. Hal inilah yang mendorong peneliti untuk menganalisa dan melihat kemungkinan strategi yang bisa membuat siswa merasa tertarik dalam mengawali berbicara tanpa merasa takut atau malu, juga mahasiswa secara otomatis akan mendapatkan tambahan kosa kata. Pada kesempatan ini peneliti mencoba menerapkan suatu metode dimana di khususkan dengan cara mengajak siswa untuk dapat aktif berbicara dengan menggunakan metode game atau permainan. Berbagai permainan yang akan di kemas sedemikian rupa untuk merangsang siswa berani dalam berbicara menggunakan bahasa Inggris. Meskipun masih banyak kesalahan dalam grammer tetapi fokus disini untuk berani dan aktif dalam. berbahasa Inggris

Belajar sambil bermain memang menyenangkan. Selain itu suasana hati yang senang bisa membuat siswa lebih mudah di dalam memahami pelajaran. Pelajaran speaking ini tidaklah mudah karena siswa cenderung mudah bosan dalam belajar. Untuk itu, pengajar harus dapat menggunakan cara yang tepat agar siswa dapat termotivasi untuk belajar bahasa Inggris. Salah satu cara yang cocok untuk mengaktifkan siswa untuk berbicara bahasa Inggris adalah dengan menggunakan sebuah permainan atau game.

Suatu permainan (Games) adalah suatu akifitas yang mengandung unsur peraturan, tujuandan rasa kesenangan. Ada dua jenis permainan yang biasa dilakukan yaitu : permainankompetisi (competitive games), dimana pemain atau tim berlomba untuk menjadi yang pertamamencapai tujuan,dan permainan kerjasama (cooperative games) dimana pemain dan timbekerja sama untuk mencapai tujuan. Jill hadfield (1984:5) menyatakan A game is an activity with rules, a goal and an element of fun. One of the most important reasons for using games is simply that they are immensely enjoyable for both teacher and student.

Seperti yang telah di kemukakan oleh Agoesetyowati, Redjeki in 102 English Game (2008:2) : Most English teachers, presenters of a workshop and speakers of seminars are using games and activities in their classroom, because games help and encourage learners and participants to sustain their interest in English. 
Agoesetyowati, Redjeki juga menambahakan in 102 English Game (2008:2) : I always play games because I realize tht games always motivate students to acquire knowledge, vocabulary, grammar, and the like.

Dari apa yang di sampaikan, peneliti sangat setuju menggunakan game untuk meningkatan kemampuan berbicara siswa dalam mata kuliah speaking. Karena cara mengajar dengan menggunakan metode games cukup menarik dan spontanitas membuat siswa aktif dalam berbicara bahasa Inggris.

Salah satu game yang akan di persiapkan oleh peneliti adalah membuat sebuah cerita, kemudian siswa meneruskannya dengan imajinasi mereka. Siswa yang tidak mampu melanjutkan cerita tersebut, maka ia akan mendapatkan hukumannya. Dibuat secara khusus untuk melatih nalar seorang siswa dan kemampuan berbicara menggunakan bahasa Inggris. Dengan menyimak atau konsentrasi penuh maka siswa bisa melanjutkan cerita dengan berbagai imajinasinya.

1. Siapkan satu buah spidol sebagai alat penentu giliran siswa.

2. Ceritakan sebuah kisah yang populer misalnya Cinderella atau pinokio namun hanya bagian awalnya saja serta putus cerita Anda pada bagian-bagian yang diinginkan.

3. Serahkan satu buah spidol kepada seorang siswa dan berikan ia instruksi agar terus mengoper spidol tersebut ke temannya sembari Anda menghitung.

4. Pada hitungan yang kelima maka siswa diinstruksikan untuk berhenti mengoper spidol.
5. Siswa terakhir yang mendapatkan spidol tersebut harus melanjutkan cerita sesuai dengan imajinasinya.

6. Ingat! Anda harus membebaskan siswa untuk melanjutkan cerita semau mereka dan jangan paksa untuk tetap pada alur cerita.

7. Setelah siswa menyelesaikan lanjutan kisah tersebut, maka teruskan menghitung dan siswa yang mendapatkan spidol pada hitungan kelima, instruksikan untuk melanjutkan cerita.

8. Siswa yang tidak mampu melanjutkan cerita, maka ia wajib dihukum untuk bernyanyi atau melakukan hal positif lainnya.

\section{METODE PENELITIAN}

Dalam kajian bab ini Peneliti menggunakan rancangan deskriptif dan korelasional. Rancangan deskriptif dimaksudkan untuk mengumpulkan informasi yang sebanyak mungkin tentang variable yang akan diteliti.

Alasan menggunakan rancangan tersebut atas pertimbangan bahwa dengan bermain game dan pengaruhnya terhadap kemampuan berbicara bahasa Inggris mahasiswa pada mata kuliah Speaking 2 atau Survival Speaking merupakan penelitian baru dalam taraf rintisan pengembangan. Oleh sebab itu peneliti akan mengkaji penerapan bermain game dan pengaruhnya terhadap kemampuan berbicara bahasa Inggris. Dalam penelitian ini di tujukan untuk mengidentifikasi peluang dan pengembangannya pada masa yang akan datang, sebagai salah satu alternative peningkatan kemampuan berbahasa Inggris. 
Penelitian ini dilakukan terhadap mahasiswa semester dua pada mata kuliah Speaking 2 atau Survival Speaking yang berjumlah 3 kelas, dan memerlukan data lapangan yang akurat, oleh karena itu pendekatan survey merupakan metode yang tepat.

Penelitian ini tegolong penelitian korelasional yang sifatnya melukiskan hubungan yang terdapat dalam dua variable (Suharsimi Arikunto, 2005:45). Penelitian ini perlu dilakukan oleh guru maupun dosen yang ingin memperbaiki strategi belajar mengajar di dalam kelas. Untuk mendapatkan data yang diperlukan, peneliti menggunakan beberapa metode pengumpulan data yaitu:

\section{Lembar Pengamatan}

Lembar pengamatan, menurut Thomas (203:60), kegiatan yang bertujuan mengumpulkan data melalui pengamatan atau mendengarkan langsung terhadap suatu kegiatan. Lembar pengamatan adalah salah satu instrumen yang sangat bermanfaat untuk mengumpulkan data tentang pelaksanaan strategi menonton film untuk meningkatkan berbicara dalam pembelajaran Survival Speaking. Dalam hal ini kolaborator bertindak selaku pengamat yang mencermati pelaksanaan kegiatan belajar mengajar.

Terdapat dua macam lembar pengamatan yang dilakukan oleh kolaborator (observer), yaitu:

\section{Lembar Pengamatan Aktivitas Dosen}

Dalam pengumpulan data ini kolaborator (observer) mengamati segala aktivitas proses belajar mengajar yang dilakukan dosen mulai membuka sampai dengan menutup pelajaran. Kolaborator memberikan checklist pada lembar pengamatan yang disusun bersama dengan peneliti (teacher-researcher). Tujuannnya adalah untuk menilai apakah dosen sudah melaksanakan langkah-langkah pembe-lajaran yang sudah disusun sebelum mengimplementasikan strategi bermain game untuk meningkatkan berbicara siswa pada mata kuliah Survival Speaking.

\section{Lembar Pengamatan Aktivitas}

\section{Mahasiswa}

Lembar pengamatan ini berfungsi untuk mengamati pelaku mahasiswa ketika beraktivitas bercerita bahasa Inggris secara spontanitas sesuai giliran yang di berikan dengan tema dan topik yang telah di tentukan.

\section{Dokumentasi}

Dokumentasi berfungsi merekam kegiatan belajar mengajar melalui media gambar dengan menggunakan digital camera.

Test

Test yang dilakukan adalah on-going test bebicara yang dimaksudkan untuk mengukur sejauh mana implementasi berbicara dengan metode bermain game dapat membantu mahasiswa berbicara, mengemukakan pendapat, mengomentari dan lancar tanpa merasa canggung atau justru terkesan tidak menghafal. Jadi test ini terintegrasi dalam process speaking, tidak diadakan waktu khusus.

\section{Kuisioner}

Peneliti memberikan kuisioner yang terdiri dari 15 item untuk mengetahui persepsi mahasiswa terhadap strategi bermain game yang diberikan. Item tersebut memiliki rentang

skor antar 1-5. 


\section{Kriteria Keberhasilan}

Untuk mengukur tingkat keberhasilan pelaksananan strategi ini peneliti dengan kolaborator menetapkan pedoman keberhasilan. Penentuan kriteria keberhasilan didasarkan kepada tujuan dari penelitian ini yaitu untuk meningkatkan kemampuan berbicara dalam bahasa inggris. Penentuan kriteria keberhasilan pembelajaran berdasarkan observasi selama penerapan metode ini. Sehingga kriteria keberhasilan dalam penelitian ini dapat dirumuskan sebagai berikut; mahasiswa mampu berbicara dalam bahasa Inggris. Setidaknya $80 \%$ mahasiswa aktif dan mendapatkan nilai minimal 75 untuk mata kuliah Speaking (berbicara). Nilai 75 (B) disesuaikan dengan tabel penilaian yang berlaku di Universitas kanjuruhan.

\section{Tekhnik Pengumpulan Data}

Peneliti akan mengumpulkan data dengan metode observasi sebagai berikut :

1. Peneliti mengobservasi metode mengajar dosen dengan menggunakan

2. metode bermain game pada mata kuliah Survival Speaking.

3. Peneliti mengobservasi aktivitas mahasiswa dalam proses perkuliahan

4. Peneliti mendokumentasikan kegiatan perkuliahan

5. Peneliti memberikan penilaian pada mahasiswa

\section{Tekhnik Analisa Data}

Langkah selanjutnya yang diambil adalah menguji hipotesis itu sendiri dengan menggunakan teori korelasi Pearson Product Moment kemudian uji signifikansi menggunakan uji $\mathrm{T}$ dan mengetahui korelasi serta prosentase kontribusi variabel $\mathrm{X}$ terhadap $\mathrm{Y}$ dengan rumus koefisien deterninasi:
$\left(\mathrm{KP}=\mathrm{r}^{2} \times 100 \%\right)$.

\section{Rumus Korelasi Pearson Product Moment (PPM)}

$$
r=\frac{n\left(\sum X Y\right)-\left(\sum X\right) \cdot\left(\sum Y\right)}{\sqrt{\left[n \cdot \sum X^{2}-\left(\sum X^{2}\right)\right] \cdot\left[n \cdot \sum Y^{2}-\left(\sum Y^{2}\right)\right]}}
$$

Dimana :

$$
\begin{aligned}
& \mathrm{r} \text { hitung }=\text { koefisien korelasi } \\
& \mathrm{X} \quad=\text { variabel bebas } \\
& \mathrm{Y} \quad=\text { variabel terikat } \\
& \mathrm{N} \quad=\text { jumlah responden }
\end{aligned}
$$

Korelasi PPM dilambangkan $r$ dengan ketentuan nilai $r$ tidak lebih dari harga $(-1 \leq \mathrm{r} \leq+1)$. Apabila nilai $\mathrm{r}=-1$ artinya korelasinya negatif seempurna. $\mathrm{R}=0$ artinya tidak ada korelasi, dan $r=1$ berarti korelasinya sangat kuat.

Sedangkan arti harga $r$ akan dikonsultasikan dengan tabel 3 interpretasi nilai $r$ sebagai berikut :

\section{Uji-T}

Pengujian lanjutan yaitu uji signifikansi hasil korelasi PPM dengan uji signifikansi (uji T) dengan rumus :

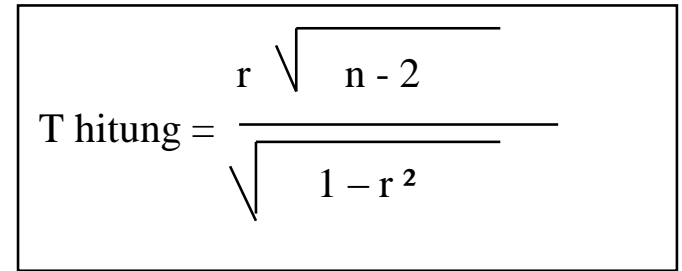

\section{Dimana :}

T hitung $=$ nilai $\mathrm{t}$

$$
\begin{array}{ll}
\mathrm{R} & =\text { nilai koefisien korelasi } \\
\mathrm{N} & =\text { jumlah sampel }
\end{array}
$$

Distribusi (tabel t) untuk a $=0,05$ dan derajat kebebasan $(\mathrm{dk}=\mathrm{n}-2)$ kaidah keputusan sebagai berikut: 
- Jika $\mathrm{t}$ hitung $\geq \mathrm{t}$ tabel berarti signifikan

- $\quad$ Jika $\mathrm{t}$ hitung $\leq \mathrm{t}$ tabel berarti tidak signifikan

\section{Mengetahui Prosentase Kontribusi Variabel X terhadap Y}

Untuk menegtahui besaran kontribusi variabel $\mathrm{X}$ terhadap $\mathrm{Y}$ maka langkah selanjutnya adalah pengukuran menggunakan teori koefisien determinasi $\left(\mathrm{KP}=\mathrm{r}^{2} \mathrm{x} 100 \%\right)$.

\section{PEMBAHASAN}

Tujuan pembelajaran bahasa Inggris di tingkat universitas adalah melatih mahasiswa untuk menguasai keempat keterampilan berbahasa, yaitu: mendengar, berbicara, membaca, dan menulis. Dalam hal ini peneliti mengukur pengaruh metode bermain game terhadap kemampuan berbicara bahasa Inggris.

Banyak cara yang bisa dilakukan mahasiswa untuk dapat aktif berbicara dalam bahasa Inggris, salah satunya adalah dengan metode bermain game. Dimana dengan bermain game tersebut dapat di lakukan dengan mengajak mahasiswa aktif dalam berbicara dengan bahasa Inggris. Dengan menggunakan Metode bermain game, banyak aktifitas yang bisa dilakukan contohnya: Ask and Answer, discussion, guessing, remembering, miming, ordering dan role play.

Pada penelitian ini, peneliti meminta mahasiswa untuk mengulas kembali topik yang telah di bahas pada pertemuan 1 dan 2, siswa untuk menceritakan kembali dan memberikan opini tentang "FAT dan LOVE' juga mengembangkan kembali sesuai dengan tambahan informasi yang mereka telah dapatkan lagi.

Hasil dari variabel X ( Strategi bermain game) dari 80 orang mahasiswa adalah 5831, sedangkan variabel Y (kemampuan berbicara bahasa Inggris) adalah 7189 . Setelah dihitung dengan menggunakan korelasi Pearson Product Moment $\mathrm{r}$ hitung adalah 0.8090

Dengan nilai 0.8090, jika diinterpretasikan sesuai dengan Interpretasi Koefisien Korelasi nilai r. Maka dapat disimpulkan bahwa nilai korelasi variabel $\mathrm{X}$ (menonton film) mempunyai pengaruh tingkat hubungan yang sangat tinggi terhadap variabel Y (kemampuan berbicara bahasa Inggris)

Setelah diperoleh t-tabel $=1.2376$. Ternyata t-hitung lebih signifikan antara strategi bermain game dengan kemampuan berbicara bahasa Inggris pada mata kuliah Survival Speaking bagi mahasiswa program studi pendidikan Bahasa Inggris.

Dengan begitu kita bisa menyimpulkan bahwa strategi bermain game mempunyai kontribusi yang sangat besar terhadap kemampuan berbicara bagi mahasiswa semester 2 program studi Pendidikan Bahasa Inggris di Universitas Kanjuruhan Malang dengan prosentase kontribusi sebesar $80.9 \%$

\section{Hasil Test}

Setelah memberikan treatment selama $2 \mathrm{x}$ pertemuan, maka pada pertemuan ke 3 dosen yang bertindak sebagai peneliti mengadakan tes untuk mengukur pengaruh strategi bermain game terhadap kemampuan berbicara bahasa Inggris pada mata kuliah speaking 2 atau survival speaking. 
Hasil dari variabel X ( Strategi bermain game) dari 80 orang mahasiswa adalah 5831, sedangkan variabel Y (kemampuan berbicara bahasa Inggris) adalah 7189. Setelah dihitung dengan menggunakan korelasi Pearson Product Moment $r$ hitung adalah 0.8090

Dengan nilai 0.8090 , jika diinterpretasikan sesuai dengan Interpretasi Koefisien Korelasi nilai r. Maka dapat disimpulkan bahwa nilai korelasi variabel $\mathrm{X}$ (bermain game) mempunyai pengaruh tingkat hubungan yang sangat tinggi terhadap variabel $\mathrm{Y}$ (kemampuan berbicara bahasa Inggris)

\section{KESIMPULAN}

Strategi menonton film memiliki pengaruh dalam kemempuan berbicara bahasa Inggris bagi mahasiswa semester 2 program studi pendidikan bahasa Inggris di Universitas kanjuruhan Malang.

, sedangkan variabel Y (kemampuan berbicara bahasa Inggris) adalah 7189 . Setelah dihitung dengan menggunakan korelasi Pearson Product Moment $\mathrm{r}$ hitung adalah 0.809

Dengan nilai 0.809 , jika diinterpretasikan sesuai dengan Interpretasi Koefisien Korelasi nilai r. Maka dapat disimpulkan bahwa nilai korelasi variabel $\mathrm{X}$ (bermain game) mempunyai pengaruh tingkat hubungan yang sangat tinggi terhadap variabel $\mathrm{Y}$ (kemampuan berbicara bahasa Inggris)

Setelah diperoleh $\mathrm{t}$-tabel $=1$. Hasil dari variabel X ( Strategi bermain game) dari 80 orang mahasiswa adalah 58312376 .
Ternyata t-hitung lebih signifikan antara strategi bermain game dengan kemampuan berbicara bahasa Inggris pada mata kuliah Survival Speaking bagi mahasiswa program studi pendidikan Bahasa Inggris.

Dengan begitu kita bisa menyimpulkan bahwa strategi bermain game mempunyai kontribusi yang sangat besar terhadap kemampuan berbicara bagi mahasiswa semester 2 program studi Pendidikan Bahasa Inggris di Universitas Kanjuruhan Malang dengan prosentase kontribusi sebesar $80.9 \%$

\section{DAFTAR PUSTAKA}

Arikunto, Suharsimi. 2010. Prosedur Penelitian. Jakarta: Rineka Cipta.

Arsyad, Azhar. 2006. Media Pembelajaran. Jakarta : Raja Grafindo Persada

Elhans. 2008. English Conversation 900. Pemeblajaran Percakapan Bahasa Inggris 900. Surabaya: Alfa.

Latief, M.Adnan. 2010. Metode Penelitian Pembelajaran Bahasa. Penerbit Universitas Negeri Malang.

Latwie, Fiona. 2004. Teaching Speaking Ability 2 - Overcoming classroom Problems (online) htpp://britishcouncil.org//accessed on January 10, 2010) http://pamanguru.blogspot.com/2012/11/hot-airballoon-game-menarik-untuk.html

Video/DVD Speaking Rubric for Fluency Activities Copyright (C) 2005 by Pearson Education, Inc. Permission granted to reproduce for classroom use 